\title{
Thinking about Roman Imperialism: Postcolonialism, Globalisation and Beyond?
}

\author{
By ANDREW GARDNER
}

\begin{abstract}
For the last twenty years or so, archaeologists of Roman Britain, among other provinces, have been seeking ways of moving beyond the concept of 'Romanisation' as a framework for thinking about Roman imperialism. Many of the ideas proposed have been drawn from two related bodies of thought which have emerged as ways of understanding the contemporary world: postcolonialism and globalisation theory. While achieving significant success in transforming interpretations of the Roman world, applications of these approaches present some fresh problems of theoretical and practical coherence. These in turn point to important issues to do with the role of theory in Roman archaeology, issues which have rarely been tackled head-on but which present obstacles to interdisciplinary dialogue. The aim of this paper is to evaluate and compare the perspectives of postcolonial and globalisation theories, assess their strengths and weaknesses, and suggest some possibilities for linking the insights of these and other approaches to define a more holistic agenda for Roman archaeology.
\end{abstract}

Keywords: postcolonialism; globalisation; institutions; power; military archaeology; rural archaeology

\section{INTRODUCTION: THEORY AND ROMAN ARCHAEOLOGY}

$\mathrm{F}$ or a field much concerned with identity of late, ${ }^{1}$ Roman archaeology has struggled to find a coherent identity of its own since the collapse of 'Romanisation' as a framework commanding broad consensus. For the last twenty years or so, archaeologists of many parts of the Empire, but perhaps especially of Roman Britain, have been seeking ways of moving beyond this concept, and a range of alternative approaches has been proposed. While some would argue that 'Romanisation' still serves a purpose, ${ }^{2}$ the broadening of the debate about our understanding of the processes of Roman imperialism cannot be denied; the question

1 Among a great many publications in recent years, see, for example, Dench 2005; Gardner 2007; Mattingly 2011; Pitts 2007; Revell 2009; Roth and Keller 2007; van Dommelen and Terrenato 2007.

2 De la Bédoyère 2007. 
is where this leaves Roman archaeology now. After a round of reflection on these developments nearly a decade ago, ${ }^{3}$ the continuing fragmentation of the previously dominant grand narrative of the sub-discipline has gone largely unremarked. It is the goal of this paper to examine the main strands of theoretical development in Roman archaeology over the last two decades, which have been drawn primarily from the literature of postcolonialism and globalisation theory, and to consider how thorough-going the transformation of the field has been. The author certainly considers 'Romanisation' to be an approach whose time has passed, and takes for granted the validity of the now numerous criticisms of this framework. ${ }^{4}$ There is little need to recapitulate these at length here, but they include its inability to capture the diversity of both processes and outcomes of Roman-period cultural change (especially as manifest in material culture), as well as its strong associations with the modern imperial contexts within which Roman archaeology became formalised as a sub-discipline. What this paper focuses on instead is the effectiveness of the ideas that have followed in the wake of this critique, and some challenges which remain in capturing the full complexity of the Roman world. In the second half of the paper, some ways of addressing these are suggested, and the question of the relevance of Roman archaeology to a wide range of other audiences is also considered. This latter issue is as crucial in evaluating the success or failure of the project of a 'theoretical Roman archaeology' as the coherence of the ideas which have been debated and deployed under this banner.

Roman archaeology has, of course, always been based upon theory in all sorts of ways, not least with respect to the workings of imperialism, and it has very frequently been incorporated into theories of empire developed by scholars in other fields. Along with the traditional grand historical narratives of the rise and fall of empire, based on cultural, military or economic explanation, from at least the time of Edward Gibbon, the particular study of acculturation processes in provincial archaeology dominated the twentieth century. ${ }^{5}$ There have been a number of variations in approach to the latter, including some making reference to broader frameworks of archaeological theory, such as Barry Cunliffe's core-periphery models, or Martin Millett's comprehensive socio-economic study of Britain. ${ }^{6}$ It is notable, actually, that while critical reaction to The Romanization of Britain opened the way for many new ideas in Roman archaeology in the 1990s, the volume itself makes rather more consistent reference to a range of archaeological approaches than a good deal of the work which was to follow under the aegis of the Theoretical Roman Archaeology Conference (TRAC). Indeed, while the establishment of TRAC has undoubtedly fostered greater discussion of theory within the sub-discipline, and particularly of the themes considered in this paper, it is not clear that it has helped connect Romanists more firmly to mainstream archaeological debates. ${ }^{7}$ On the contrary, while scholars from other disciplines have often drawn upon Rome in examining the broad theme of empire - in a long tradition extending from nineteenth-century social theorists through to more contemporary comparative historians and political scientists ${ }^{8}$ - and the more recent work of some Romanists has been represented in comparative archaeological studies of this theme, ${ }^{9}$ in many other areas the potential contribution of Roman archaeology is ignored. Once lauded as

e.g. the conference 'Whither Roman Archaeology?' in London in 2002, see Gardner 2003; James 2003; cf. also Laurence 2001; Reece 1997; Woolf 2004.

e.g. Barrett 1997; Freeman 1993; Hingley 1996; Mattingly 2004; Webster 2001.

Hingley 2000, 109-65; Rogers and Hingley 2010; Webster 2001, 209-17.

Cunliffe 1988 (in some ways a pre-cursor to contemporary globalisation debates); Millett 1990.

cf. Hingley 2001, 112; Laurence 1999a, 387, 390; Woolf 2004, 420.

Morrison 2001, 1-3; e.g. Doyle 1986; Münkler 2007. While imperialism waned somewhat as a topic in the post-War period, the debate about globalisation has in many ways given it new impetus.

e.g. Given 2004; Gosden 2004; Stein 2005. 
highly promising, ${ }^{10}$ that potential has not yet been realised. ${ }^{11}$ Is this something we should care about, and if so what can we do about it?

The answer to the first of these questions partly depends upon whether we take a narrow or a broad view of the goals of Roman archaeology - whether we see it as an end in itself, or a means to an end. Even if the former, there is surely much to be gained from dialogue with other archaeologists just as there is from ancient historians and classicists. If we take the latter view, then engaging more fully with archaeological theory is a necessary step in contributing to the wider project of archaeology as a critical social science, and also as a discipline with a highly public face. The rarefied language of some theoretical literature may seem utterly incompatible with the needs of a public archaeology, ${ }^{12}$ but the issues at stake are certainly not: themes like identity politics and human relationships with the material world have scarcely been more salient in public consciousness than now. ${ }^{13}$ While Roman archaeology can make major contributions to all kinds of debates, such as whether cultural change should be understood from an evolutionary perspective or not, ${ }^{14}$ clearly the problems of imperialism, colonialism and culture-contact form a nexus around which all other issues revolve. While the major theoretical developments of the last two decades have very much focused on these issues, in evaluating these there is a need to consider a more basic question: what should the role of theory in Roman archaeology be? At one level it might assist with the description of different features of the Roman world (from those encountered in excavation to institutional structures), perhaps from different points of view and inevitably as an interpretive process. At another, it might help us to analyse or explain the underlying processes of empire, and how these were linked with everyday life, and thus with the archaeological record. And it will also play a role in how we judge - that is if we choose to judge, though it can be rather difficult to avoid ${ }^{15}$ - Roman imperialism. In all of these respects, theory can also be used to structure appropriate comparisons, within and beyond Roman culture, and of course comparison is essential to an outward-facing discipline. While some of the wider ignorance of recent developments in Roman archaeology is hardly the fault of Romanists, a failure to be clear about the ways in which theory is being used, as well as a relatively limited degree of follow-through in the implementation of innovative ideas adopted, are also partly to blame for this situation. The result is that, in spite of the important developments that have taken place, Roman archaeology is on the whole still under-theorised in comparison to many other areas of archaeology. ${ }^{16}$ However, in what follows it will be argued that our field is actually in a strong position to reconnect not only with some of the key concerns in archaeological theory (and that of other disciplines), but also to push them in new directions. Before expanding upon this point, the important areas of postcolonial and globalisation theory will be examined.

\section{FRAGMENTING THE EMPIRE: POSTCOLONIAL APPROACHES}

Readings of postcolonial theory have driven many of the recent steps forward in Roman archaeology, both in terms of critical historiography and substantive re-interpretation of the

10 Hodder 1993, xviii.

11 Johnson 2010, for example, contains scarcely any reference to studies based on Roman material.

12 Mattingly's use of 'discrepant experience' has been criticised, for example: de la Bédoyère 2007; Fulford 2007, 368; cf. Mattingly 2011, 213; also Laurence 2006, 124-5 on presentation.

13 e.g. Meskell 2002; cf. Hingley 2003, 119; Witcher forthcoming. At the time of writing, the new issue of the $B B C$ History Magazine (13.2, February 2012) includes a cover-page and feature on the British Empire, including its effects on Britain itself and the identities of colonised people.

14 See, for example, Cochrane and Gardner 2011; cf. Biddulph 2012; Greene 2006.

15 The reviews of, and response to, Mattingly 2006 show how prominent this issue is, see Mattingly 2011, 274-5.

16 In this respect, even the most recent TRAC volumes do not reveal a decisive shift since Laurence 1999a, see Gardner 2012b; cf. Gardner 2006; Laurence 2006. 
Roman world. Postcolonialism is, though, an ambiguous term to define, referring both to a contentious interpretation of the modern world (or parts of it) and to a rather diverse set of concepts and research projects which have sought to critique and challenge traditional Eurocentric history and other forms of representation. Use of the word immediately raises difficulties to do with the meaning of 'imperialism' versus 'colonialism', ${ }^{17}$ and whether the age of empire has passed, while the writings of postcolonial theorists can in themselves be challenging in their blend of schools of thought including Marxism, post-structuralism and psychoanalysis. ${ }^{18}$ To generalise, postcolonial theory has offered three main approaches to the nature of empire: an initial phase of 'nativist' critique that highlighted resistance to colonial oppression, and then subsequently a range of studies of the way colonised peoples have been represented in colonial literature (colonial discourse analysis), and also of the complex nature of colonial identities, emphasising their locally-variable hybridity. All three of these themes have found a home in Roman archaeology. ${ }^{19}$ While straightforwardly 'nativist' reinterpretations of Roman occupation in terms of indigenous resistance and continuity flourished relatively briefly before being overwhelmed by criticism of their perpetuation of Roman-Native polarity, ${ }^{20}$ the need to capture some sense of the struggle embedded in colonialism has never gone away (see below). More obviously successful and influential, though, have been applications of the other main strands of postcolonialism. Colonial discourse analysis has been widely put to use in the study both of Roman-period texts as instruments of imperial ideology, and of modern historical writing about the Roman Empire created within the context of more recent empires, particularly that of Great Britain. ${ }^{21}$ Meanwhile, a proliferation of studies of identity in the Roman world have drawn upon postcolonial literature, among other sources of identity theory, ${ }^{22}$ to explore the complexities of provincial cultures which had been obscured by the simplistic culture-change model offered by theories of 'Romanisation'.

These developments have been extremely important. The reading of classical sources not simply as straightforward renderings of historical reality, but as utterly implicated within colonial mentalities, liberates Roman archaeology from historical over-determination, and offers the enticing prospect of treating such texts as material culture. ${ }^{23}$ That something as essential as genuinely critical reading of such sources should require postcolonial influence to inspire - at least within Roman archaeology, as distinct from history or classics - is perhaps difficult to credit. However, the coincidence of an avowedly post-imperial and also thoroughly archaeological account of Roman Britain in Millett's Romanization ${ }^{24}$ is an important signal that these trends are related, and that the previous reliance on Roman sources for the narrative structure of the sub-discipline went hand-in-hand with a generally positive view of the Empire itself. ${ }^{25}$ This much is revealed, in turn, by postcolonial readings of the literature created within the nineteenth and much of the twentieth centuries which defined the agenda of Roman

Terms used fairly freely throughout, since they are in much of the literature; cf. Webster 1996a.

Krishna 2009, 3-4, 63-104; Loomba 2005, 12-22; Lydon and Rizvi 2010b, 18-20; Young 2001, 57-69.

Mattingly 2011, 26-30; Webster 1996a, 6-7; cf. Lydon and Rizvi 2010b, 20-6.

Dench 2005, 83-5; Mattingly 1996, 57-9; Webster 1996a, 6-7; 2001, 212-13, 216-17; cf. Loomba $2005,21$.

e.g. Forcey 1997; Hingley 2000; 2008; Webster 1996b.

e.g. Hingley 2005, 91-116; Mattingly 2004; cf. Pitts 2007.

cf. Gardner 2007, 35-9; Johnson 1999; Moreland 2001.

4 Millett explicitly sought to minimise the role of textual sources in his account, as well as advancing a wide range of analytical approaches to material patterning; see, for example, Millett 1990, xv-xvi; cf. Hingley 2001, 112; 2007, 536.

Limited source criticism is a problem common to the earlier stages of other historical archaeologies, too, and partly accounted for by the distinct goals of such sub-disciplines; Andrén 1998, 1-4; Moreland 2001, 9-21. While classicists and ancient historians have unsurprisingly been more effective than archaeologists at critique of ancient texts, a postcolonial turn in this is a relatively recent phenomenon, e.g. Bradley 2010; Goff 2005; Hardwick and Gillespie 2007; cf. Hingley 2005, 4. 
archaeology from its inception. A considerable body of work has now demonstrated very thoroughly the manifold — but sometimes not straightforward — connections between scholarly (and popular) views of Rome, and contemporary views of Western imperialism, that in some respects continue to this day. ${ }^{26}$ This aspect of postcolonial Roman archaeology is perhaps most closely connected to applications of postcolonialism in other sub-disciplines of archaeology. ${ }^{27}$ There is thus the potential for much greater interchange between this kind of work and histories of archaeological thought created by others, even if the question of whether such self-critique makes the archaeologist more objective, or merely more attuned to their own inevitable subjectivity, is rather unresolved. ${ }^{28}$ Equally significant — though perhaps now slightly out-of-step with developments in other areas of archaeology — is research on identity. While several studies have been based more on sociological theories of identity, there is no doubt that the emphasis in much postcolonial literature on the multiple overlapping and hybrid identities of colonised peoples (and their colonisers), described by terms such as 'creolisation' and 'discrepancy', have been influential, and have contributed to the much fuller understanding of local provincial societies. ${ }^{29}$ Whether some uses of the language of 'identity' really represent a break with the past has been questioned, ${ }^{30}$ but a more important issue is where we go from here. While identity remains a pertinent issue in many areas of archaeology (and this relates directly to the relevance of the discipline in the twenty-first century), ${ }^{31}$ there are several aspects of the wider debate which Romanists have yet to seriously tackle - from major categories of identity such as gender ${ }^{32}$ to the complex issue of self-identity and the fundamental relationships between people and changing material cultures.

While not all of the discussion of the latter theme in other areas of archaeology has been fruitful, there is a debate here to which Roman archaeologists should have much to contribute. ${ }^{33}$ This is not merely because of the oft-remarked strength of our empirical resources, but also because there are highly relevant areas of postcolonial theory that have yet to be thoroughly explored. There has been much discussion in postcolonial studies about the nature of colonised (or 'subaltern') agency, and whether the strong influence of Western theory, particularly postmodernism, empowers or smothers the distinct voices of people who may undergo profound material and personal transformations through the experience of colonialism. These will frequently arise through the need to sustain contradictory performances in interactions with different people, including those representing the colonising power (this is another form of 'discrepancy' at the level of self-identity). ${ }^{34}$ There is a danger that if we limit

\footnotetext{
26 e.g. Hingley 2000; 2008. See, for example, papers in Winkler 2004 on more contemporary popular representation.

27 e.g. Díaz-Andreu 2007; Gosden 1999; Johnson 2010, 205 (cf. note 11 above; this is the only reference to recent developments in Roman archaeology).

28 Kohl and Fawcett 1995; Trigger 2006, 38-9.

29 e.g. Gardner 2007; Mattingly 2004; 2006; Revell 2009; Webster 2001. 'Creolisation' is an approach drawn from
} American historical archaeology and championed particularly by Webster, seeking to highlight the relationship between material hybridity and power inequality; cf. Mattingly 2004, 7 and Roth 2007, 19 on issues with the term. 'Discrepancy' is a term deployed especially by Mattingly, following Said, to highlight not only the existence of diverse identities in a Roman province, but also the very different experiences of different groups; cf. note 12 above.

30 Pitts 2007

31 e.g. Casella and Fowler 2005; Díaz-Andreu et al. 2005.

32 Baker 2003; Laurence 1999a, 388-9; Revell 2010.

33 Identity studies in Roman archaeology have successfully opened up the complexities of group identities, but the dynamics of self-identity, agency and personhood in relation to the material world have yet to be thoroughly explored. Gosden 2005 is unconvincing in applying the notion of 'object agency' to Roman-period material culture, in my view (cf. Mattingly 2011, 235), but this is still a rare discussion of some of the issues; see Barrett 1997; Greene 2008 for other examples.

34 Krishna 2009, 63-130; Loomba 2005, 7-41, 192-212; O’Hanlon and Washbrook 1992; Poitevin 2002; cf. Given 2004, 8-25; Gosden 2004, 104-13, 153-9. 
our application of postcolonial theory to attempts to describe provincial cultures as composites of fragmentary, fluid and hybrid identities, seemingly involving a fair degree of choice and flexibility, we will fail to analyse the power relationships that create and sustain inequality. ${ }^{35}$ Partly this requires us to recognise the continuing role of violence in imperial society, ${ }^{36}$ but also it necessitates a deeper engagement with theories of agency, personhood and the significance of material transformation to everyday life, and a concomitant interest in the structural characteristics of Roman imperialism as a process. ${ }^{37}$ If the latter can be embraced - and more will be said on this below - we will actually be transcending one of the weaknesses of postcolonial theory in general, which has (perhaps surprisingly) been criticised for failing to get to grips with serious political analysis. ${ }^{38}$ So far, few of the postcolonial studies in Roman archaeology have tackled these kinds of issue, but pushing further with them will not only help Romanists engage with mainstream archaeological debates, it will also help clarify the current confusion over whether postcolonial influence simply means a shift in our judgement of Roman imperialism, from 'good' to 'bad'. ${ }^{39}$ Of course it could be either - this is the point of a phrase like 'discrepant experience' 40 — and analysing how these experiences shifted requires us to think more seriously about power as well as about the relationship between past and present. Does the second major strand of theoretical discussion about the nature of the Roman Empire offer the answers?

\section{SYSTEM AND SCALE: GLOBALISATION APPROACHES}

Theories dealing explicitly with globalisation have been making their presence felt in Roman archaeology for less time than postcolonialism, and consequently are represented by a smaller (but certainly growing) literature within the field. ${ }^{41}$ Like postcolonial theory, though, these consist of an eclectic set of approaches to primarily modern global transformations, and indeed the two traditions share several common concerns, such as the formation of hybrid identities, and also a problem of whether the label is descriptive or analytical; the answer to this, as with postcolonialism, bears marked political connotations. Different approaches to globalisation have different theoretical origins and different judgements as to the virtues of the situation. Some more critical approaches draw, like much of postcolonialism, upon Marxism, particularly the analysis of commodification and alienation; others conform more to a neoliberal economic template. ${ }^{42}$ Consequently, even defining 'globalisation' is problematic, and while one common thread is marked transformations in spatial connectivity (on supraterritorial or transplanetary scales), there is much debate across a range of disciplines about the limits of such phenomena spatially and historically, and indeed about whether the concept is simply a vacuous gloss for

35 González-Ruibal 2010, 45; cf. Faulkner 2008, 68-70; Hingley 2001, 114; forthcoming; Mattingly 2010, 290; 2011, 75, 216-17, 271-2; Witcher forthcoming.

36 James 2001a, 198; cf. Giddens 1985, 35-60.

37 Scott 1993b, 13-15 identified some of these issues as crucial at the outset of TRAC. Cf. Gardner 2011 for a review of subsequent theoretical developments.

38 Krishna 2009, 111-19; Loomba 2005, 20, 39-41.

39 Selkirk 2006; cf. Faulkner 2008 for a more purely Marxist, and more polemical, critique of imperialism, and Witcher forthcoming for a balanced view.

40 Mattingly 2006, 525; 2011, 274-5; cf. Said 1993, 37-9.

41 e.g. Hingley 2003; 2005; Hitchner 2008; Pitts 2008; Ratliff 2011; Witcher 2000; as with applications of postcolonial theory, Roman archaeology is keeping pace with wider archaeological debate here (cf. Jennings 2011), though perhaps not contributing to it as directly as would be ideal. Previous discussions of world-systems theories across a number of archaeological sub-disciplines also foreshadow many of the issues, cf. Greene $2008,79$.

42 Krishna 2009, 2-4, 7-30, 155-72; Rosenberg 2000, 1-9; Scholte 2005, 13-48. 
neo-colonialism. ${ }^{43}$ The diverse literature on globalisation undoubtedly offers some interesting, and potentially useful tools to Romanists interested in networks and communication, consumption, identity, and the interaction between small- and large-scale phenomena, but there are serious questions to do with the utility of, and political implications of, the application of some of the vocabulary of globalisation to the Roman world. ${ }^{44}$ Before expanding on these, it is worth elaborating on three of the major themes that have found most favour in Roman archaeology thus far: communication, consumption, and 'glocalisation'. A key feature of many definitions of globalisation is the recent transformation in the speed and reach of means of communication, both in terms of movement of goods or people, and of information. The consequences of these changes for personal relations, the construction of identity, and the formation of new networks of interaction have been argued to be profound, bound up with experience of time and space, though there is some uncertainty over whether these phenomena are cause or consequence of globalisation, and indeed of how pervasive they really are. ${ }^{45}$ Another, closely related theme has to do with economic developments often considered characteristic of capitalism, such as the expansion of commodification to new domains, and the growth of consumerism. ${ }^{46}$ While these concerns both tend to emphasise the increasing domination of a particular way of life, there has also been considerable interest in how such transformations play out differently in different places, often creating new and perhaps hybrid forms of local identity - a phenomenon known by the term 'glocalisation'. ${ }^{47}$ This latter point particularly accounts for the interest shown in theories of globalisation by Romanists seeking a way forward beyond 'Romanisation'.

This is because a persistent problem in theorising the Roman Empire is that of scale - how to encompass both empire-wide phenomena and local experience within one framework which does justice to both. Put crudely, whereas traditional 'Romanisation' approaches tended to be top-down and homogenising, the influence of postcolonialism has generated studies which err towards the bottom-up, and the heterogeneous. ${ }^{48}$ Creating a linkage or reconciliation between these different scales seems both essential and elusive. Studies of 'glocalisation' in the Roman world are thus an important experiment in solving just this problem, and they have been attempted within different provincial contexts. Such studies tend to emphasise exchange (which might be political or symbolic as well as material) as the common mechanism connecting individual regions with the wider world, but with variable outcomes, including the formation of new local hybrid identities. ${ }^{49}$ Other studies have explored the particular mechanisms of communication which created novel networks within the Empire, whether in the form of physical structures like roads or new interactions, particularly, again, through trade. ${ }^{50}$ The latter theme is also of course essential to interpretations of changing patterns of Roman-period material culture in terms of consumerism, that is the active choice of strictly unnecessary mass-produced goods. ${ }^{51}$ The most synthetic study which explores all of these themes across a wide geographical extent, and critically blends insights from some of the overlapping strands of postcolonial and

\footnotetext{
43 Hitchner 2008, 1; Naerebout 2007, 154-8; Nederveen Pieterse 2009, 7-21; Scholte 2005, 49-84; Witcher forthcoming.

44 cf. Hingley 2003, 118-19; Greene 2008, 79-80; Naerebout 2007; Rothe 2006, 443. A somewhat similar point has been made about 'creolisation', cf. Roth 2007, 19.

45 Giddens 1990; Scholte 2005, 59-75; Urry 2000; cf. Adam 1994; Rosenberg 2000.

46 Krishna 2009, 31-61, 156-72; Naerebout 2007, 155; Scholte 2005, 159-84.

47 Scholte 2005, 26, 80, 224-55; this is a well-established theme in anthropology, see, for example, Miller 1995.

48 cf. Hingley 2003, 115-17; Mattingly 2010, 284-5; 2011, 38-41; Witcher 2000, 217-18, 220-3; Woolf 2004,

424.

49 Pitts 2008; Witcher 2000; cf. Hodos 2010, 23-7; Witcher forthcoming.

50 e.g. Laurence 1999 b, put into the context of more explicit globalisation theory in Laurence 2001, 98-101.

51 e.g. Ratliff 2011; cf. Scholte 2005, 163. This strand exists in some tension with studies of consumption more generally, cf. Greene 2008; Martins 2003; Pitts 2004.
} 
globalisation theory, is Richard Hingley's Globalizing Roman Culture.52 This combines an analysis of the creation of an empire-wide 'Roman' culture as an élite phenomenon with a characterisation of a much more fragmented series of experiences for the vast majority of the Empire's inhabitants. ${ }^{53}$ While there is a degree of ambiguity in the way globalisation is discussed in this volume, ${ }^{54}$ it makes the important point that if we are living in a globalised world, studies of the Roman Empire which deploy globalisation theory make themselves relevant by speaking directly to contemporary concerns. ${ }^{55}$ The question remains, though, as to whether this is doing so in the most appropriate way.

This brings us to some of the problems of globalisation approaches as currently deployed in Roman archaeology. The complex issue of the relationship between past and present is perhaps foremost among these. ${ }^{56}$ While there is considerable debate within globalisation studies as to the historical roots of the process, with some arguing that early manifestations of 'globality' occurred in antiquity (particularly within the framework of world-systems approaches), ${ }^{57}$ it can certainly be argued that key structural features of the contemporary world and the Roman world are not shared. For example, on the one hand, and in spite of what we increasingly understand about the variability of the Roman world, it cannot be argued to be as economically differentiated as the modern world, and of course that differentiation - in the form of massive inequality - is absolutely central to key elements of globalisation, such as the outsourcing of labour and the commodification of waste. ${ }^{58}$ On the other hand, while violence still plays a role in maintaining the dominance of certain (increasingly entangled) national and corporate interests, it is a relatively much less significant part of the institutions of globalisation compared with the Roman Empire, within which the military was perhaps the pre-eminent state institution. ${ }^{59}$ Now, some such structural differences between the Roman and contemporary worlds are certainly acknowledged by proponents of an encompassing definition of globalisation (whether understood as a continuous long-term process or a sequence of discrete globalisations) ${ }^{60}$ However, the greater the range of variation encompassed by the term, the less useful it becomes as framing any kind of analytical approach, and the more it seems to be simply a synonym for connectivity or networks, or, worse, 'Romanisation'. ${ }^{61}$ Again, the use of 'globalisation' more as a descriptive than as an explanatory term is accepted by some of its advocates, ${ }^{62}$ but this clearly sets limits to the theoretical role which such a perspective might play. Even in this descriptive role, there is a danger that identifying similarities between the Roman Empire and aspects of contemporary globalisation serves to legitimise current inequalities, particularly if a long-term evolutionary

52 Hingley 2005.

53 cf. Krishna 2009, 167-8, on the complicity of colonised élites in more recent empires.

54 Naerebout 2007; Hingley forthcoming.

55 Hingley 2005, 117-20; cf. Hingley 2003, 118-19; Witcher forthcoming.

56 cf. Hingley forthcoming.

57 Denemark et al. 2000b, xix-xx; Frank and Gills 2000; Scholte 2005, 85-91; cf. Pitts 2008, 493, who simply asserts that this is the case. Other 'globalisation theorists' see a more decisive break, e.g. Giddens 1990.

58 Greene 2008, 79-80; Morley 2010, 95-101; cf. Krishna 2009, 156-66; Scholte 2005, 159-84, 316-47. Clearly this issue recalls the long-running debate over the nature of the Roman economy, see Morley 2010, 70-4 for a recent summary.

59 Giddens 1985, 2-5, 22-60; James 2011, 136-7; Malešević 2010, 119-20, 311-14; Scholte 2005, 71; cf. Krishna $2009,131-54$ on the continuing role of military intervention, and Cioffi-Revilla 2000 for an overly-simplistic long-term perspective on conflict. Hingley 2001, 114 and Mattingly 2011, 19-26 remark on the need to address this issue in Roman archaeology.

60 Hopkins 2002; Jennings 2011, 1-34; Witcher forthcoming; cf. Scholte 2005, 85-91.

61 Naerebout 2007, 157-67; cf. Witcher forthcoming, who argues that nonetheless it is usefully conspicuous as a 'modern' descriptive term, and Hingley forthcoming, who notes that where it is used analytically, it tends to be so in a reductive, positivist fashion; Jennings 2011 is an example of this, I would argue, while Hitchner 2008 seems not to apply 'globalisation' in a fashion which is clearly distinct from 'Romanisation'.

Pitts 2008, 494, 504; Witcher forthcoming. 
connection is posited between the two contexts. The writer accepts that there is a strong case for refreshing the basis we use for judgement of the Roman Empire, and - more so than with nineteenth-century imperialism - current debate about the moral complexities of globalisation should inspire more plural views of the relevance of the Roman past. ${ }^{63}$ Where globalisation approaches seem to be inadequate, however, is in providing analytical tools for examining that Roman past as a distinctive social world. Aside from usefully highlighting the importance of economic dimensions which postcolonial theory had perhaps steered away from, such approaches leave us still seeking a way of understanding the process of Roman imperialism. Fortunately, as the next section will argue, the conceptual tools with which to pursue such an understanding have been with us for some time, but have yet to be thoroughly worked through.

\section{THE MISSING LINK? INSTITUTIONAL ARCHAEOLOGY}

The connected threads of postcolonial and globalisation theories have certainly moved Roman archaeology forward over the last two decades, offering a range of new ways of looking at the Empire and experience within it. However, there continue to be problems with theoretical clarity (in terms of whether these ideas play more descriptive or analytical roles in our thinking), with how we understand the relationship between past and present, and perhaps most importantly with articulating the different scales of phenomena which characterise the specific (yet, of course, dynamic) social formation of the Roman Empire. In seeking to address these, elements of both major perspectives discussed above will be drawn upon, but an effort will also be made to reconnect them with other concerns that have been aired in the wider archaeological discipline, especially with regard to the relationship between the micro and macro scale. In particular, the relationship between social structure and human action will be revisited, with the focus on the role of institutions in daily life. As an aside, the author is aware that the stress placed here (and in the foregoing) on the interaction between Roman archaeology and archaeology at large is likely to be seen as simultaneously exacerbating the division between Roman archaeology and ancient history or Classics. ${ }^{64}$ Yet an alternative perspective is to suggest that textual materials can readily be incorporated into an archaeological framework that treats them as particular kinds of object with a very particular context of use, just as archaeologists in other historical periods have done. ${ }^{65}$ In this way they can be integrated into the broad concern with the materiality of past lives - including all of those of no concern to ancient writers ${ }^{66}$ — that surely characterises Roman archaeology just as much as any other kind. This point indeed is very evident in the particular aspect of the Roman Empire that will be the focus of the initial case-study in this section, which relates to the archaeology of the military community, but there is both an irony and an apology to note here. The irony is that, because of the association between traditional approaches to Roman imperialism and narratives of military conquest (seen as at least a necessary, if not a commendable thing), ${ }^{67}$ much of the early discussion of postcolonial approaches sought to move away from study of the military and look to wider social and economic phenomena; it has taken a further shift of perspective for some Romanists to turn again, with a much more critical gaze, to military life, and in some

63 Especially where the Roman world is directly referred to by scholars in other disciplines, e.g. Hardt and Negri 2000, 314-16; cf. Hingley forthcoming; Witcher forthcoming.

64 Dench 2003; 2005, 6-7, 83-5, 231-3; and perhaps also between Anglophone and other traditions; cf. Frere 1988, 36 , for a similar sentiment in the early days of explicitly theoretical Roman archaeology.

65 Johnson 1999; Moreland 2001; see, for example, Leone 2005 for an extended case-study.

66 Hingley 2005, 11; 2007, 536-7; cf. Given 2004, 3-4.

67 Scott 1993b, 7-8, noting that the dominant interest in the military had been descriptive rather than analytical; cf. Peddie 1994 as an example of countless books lauding the success of the Roman military. 
respects the archaeology of military communities has been at the forefront of recent theoretical developments. ${ }^{68}$ The apology relates to the fact that the military may well seem an easy choice to illustrate the following discussion of the role of institutions in articulating smaller and larger social scales, and to some extent this is true. Subsequently, though, in addition to the military case, this paper will explore some of the range of other institutions that are evident in the archaeology of Roman Britain. In doing so, it is hoped to demonstrate that the approach advocated here is one way of addressing the shortfall in wider recognition of Roman archaeology's contribution to substantive questions about the human past.

This shortfall has been, indirectly, identified by Colin Renfrew in a recent interview: 'I think one of the central problems in archaeology today is how to deal with large political units and power structures, how to make sense of them. [...] I think postprocessual archaeologists have completely neglected that field.' ${ }^{69}$ Now some Roman archaeologists influenced by aspects of postprocessual theory have already been making headway in dealing with state structures for the past decade or so, by significantly reconceptualising the Roman military, and focusing upon the understanding of multiple military communities and identities, rather than a monolithic 'Roman army'. ${ }^{70}$ However, where this work has further to go - and this is what makes Renfrew's remark relevant and indeed inspirational - is with respect to the power dynamics that constitute military (and other) communities. While the notion of communities has enabled us to get a better grip on the kinds of practices that both defined and overlapped boundaries between soldiers and others, this has not necessarily helped us keep in mind the inequalities of power embedded in such relationships, and the coercive force which at times reinforced these. ${ }^{71}$ The questions posed by postcolonial approaches (about the fundamental power inequalities built into colonialism) and globalisation theories (about the way in which different social scales can be connected) are still hanging, therefore. Moreover, these questions need to be pursued with respect to the wide range of other institutions which structured Romano-British society. An increasing number of studies of the relationship between practices (typically understood as routine activities) and identities have been pushing in the right direction. These have been successful not only in capturing more of the diversity of experiences of Roman imperialism than hitherto, but also highlighting the agency of more people throughout provincial society in shaping that society. ${ }^{72}$ However, holistic approaches to comparing a broad spectrum of different practices, and thus unpicking the interplay of different institutions, are still rare. As a result, the interconnection of practice and action at the small scale with the structural dimensions of Roman society is insufficiently developed, and in turn this inhibits our understanding of the fundamental constitution of agency and self-identity for different people within this society. In other words, it can be argued that before effective comparisons either with later empires or with the globalised present can be made, there is a great deal of work still to do with theoretical tools that were introduced to Roman archaeology at the beginning of TRAC's existence. The way in which this situation mirrors that in archaeology more generally will be examined later, but for now the discussion will expand a little more on the nature of institutions, before offering two illustrations of their impact in different contexts.

\footnotetext{
68 See, for example, Millett 1990, xv, on moving away from military history (this is perhaps linked also to wider trends in later twentieth-century academic treatment of violence; James 2011), and, from the other side of the argument, Frere 1999, xvii. Cf. now Hingley 2001, 114 and Mattingly 2011, 19-26 on re-emphasising power and domination, and James $2001 \mathrm{~b}$ on revivified approaches to the military, which form a key part of the argument in, for example, Hingley 2010 .

69 Harding 2008, 161

70 e.g. Collins 2008; Gardner 2007; Haynes 1999; James 1999; 2001b; Roymans 2004

71 A consequence of this appears to be that Roman military archaeology is making a surprisingly small contribution to the gradually increasing comparative studies of the archaeology of violence, for example Otto et al. 2006.

72 e.g. Pitts 2007; Revell 2009; Mattingly 2011.
} 
Although social structure can be understood in a number of ways, 'institutions' are central to most accounts, and constitute a primary manifestation of stability in social life. ${ }^{73}$ They can be thought of quite loosely, as structures of knowledge which frame how people act in different circumstances. This knowledge is frequently habituated and taken-for-granted, but because ultimately institutions are abstractions which only fully exist in the way they are put into practice, they are always subject to the vagaries of practice and to the political contestation that this makes possible. The stability of institutions requires effort. Seen in these general terms, institutions can take many specific forms, from conventions of interaction (such as marriage and kinship), to broad categories of identity (like ethnicity), through to more specific corporate groupings, which we might further distinguish as 'organisations'. ${ }^{74}$ In all cases, though, insofar as institutions structure practice, they are highly amenable to archaeological investigation. The detection of patterning in archaeological materials which can be interpreted in terms of practices is now reasonably well-advanced in Roman archaeology, through a range of detailed methods of analysis of artefactual assemblages and spaces. ${ }^{75}$ By comparing similarities and differences in patterns of practice over time and space, indications of the characteristics of institutions can be discerned, as can their relative structural 'weight' upon the individuals whose actions both perpetuated and, sometimes, transformed them. ${ }^{76}$ The role of structures in shaping different kinds of individuals is thus in turn revealed. ${ }^{77}$ Rather than embark on a fuller theoretical exposition of these points here, some of the key issues will be illustrated with discussion of two examples highlighting, on the one hand, the transformative effects of military organisations upon soldiers as both the perpetrators and subjects of Roman imperialism, and on the other the ways in which the actions of people living in rural contexts gave shape to a range of other, broader kinds of institutional structure in Roman Britain.

While a range of long-established approaches to the Roman military have emphasised the role of forts and fortresses as centres of control for surrounding populations, more recent 'community' approaches have discussed the interactions binding soldiers into a particular kind of group, permeable also to non-soldiers living around such sites. ${ }^{78} \mathrm{~A}$ further facet of the archaeology of military sites, though, which is relevant to the analysis of the institutional effects of military practice upon its participants, is the extent to which such places were also locales within which power was exerted over - yet also contested by — the people recruited into this major element of the Roman state. An examination of the construction and inhabitation of any military site reveals the contours of this 'dialectic of control'. ${ }^{79}$ While the relatively high degree of repetition in military layouts, and central features of their architecture such as the communal space of the principia, ${ }^{80}$ offered unifying possibilities both within the unit and the wider military community, in most respects the architecture of a fortress like that at Caerleon (to take the site with probably the best-known archaeology for its type in Britain) emphasises the

73 Giddens 1984, 16-34; 1985, 1-22; Jenkins 2004, 132-7; López and Scott 2000, 1-6. Note that here a much more flexible view of institutions is envisaged than the 'total institution' model employed by, for example, Pollard 1996; cf. also Faulkner 2008 for a different take on 'structure', but one which rightly emphasises its theoretical importance.

74 Jenkins 2004, 132-44; López and Scott 2000, 19-42.

75 e.g. Allison 2009; Gardner 2007; Pitts 2010; cf. Lightfoot et al. 1998 for an early application of the practice approach in a different culture-contact situation.

76 See Gardner 2007 for a detailed exposition in relation to the military.

77 The historical variability in the understanding of individuality has led some to dismiss the whole agenda of 'agency and structure', for example Thomas 2004, 121-2; cf. Fewster forthcoming. However, while Giddens specifies a range of aspects of distinctively modern individuality, his broader approach to the interconnection of agency and structure is more generally applicable (e.g. Giddens 1991, 74-5; cf. Jenkins 2004, 10-14; Porter 2010). As such I believe it is a more appropriate framework than 'globalisation' for analysing the Roman past.

78 e.g. Hanson 1997 on control; van Driel-Murray 1995 and James 2001 b on the community and its boundaries.

79 Giddens $1985,10-11$

80 Driessen 2005. 
hierarchy within the legion, most obviously in the space allowed to ordinary legionaries, centurions, and senior officers. As Simon James has argued, this hierarchy was enforced through training and a host of other routines of practice that even a citizen recruit must have been forcefully transformed by. ${ }^{81}$ To highlight one small element of this, the evidence from the Fortress Baths at Caerleon (FIG. 1) speaks to both the imposition of discipline and the potential for discord that defined military practice in dynamic ways over time. The baths were a priority in the construction of the fortress of Isca, and although later modifications would expand the complex, ${ }^{82}$ the importance of bathing as a practice which promoted both solidarity and bodily transformation (in conjunction with equipment and training ${ }^{83}$ ) was clearly paramount. Yet the baths were also an arena for more unstructured interaction, with the finds providing evidence of gambling, casual food consumption and the potential for socialising with non-soldiers. Even so, the presence of officers among the bathers (judging from some of the small finds) meant that the hierarchy was never entirely absent, and there is possible evidence, in the form of part of a scourge, for the physical imposition of this hierarchy, probably against slaves servicing the facility. ${ }^{84}$

Thus, hierarchy, backed up by violence, was as crucial to the structuring of life within the military as to the role of the military in the expansion and maintenance of empire, and it was sustained not simply by an anonymous system, but by the individuals in positions of authority within the legion. ${ }^{85}$ The soldiers might benefit from complicity with this structural inequality, but could also act against it from within, in a range of ways. Even as the institutional weight of the militarised state increased into late antiquity (manifest in increasing layers of administrative control, for example), so variation in small details of local practice increased. At Caerleon, the archaeology of this period is somewhat controversial, but even in the later third century A.D., when military occupation is not disputed, there are variations in the manner of rebuilding of some of the barracks. ${ }^{86}$ If the continued presence of some sort of legionary garrison is accepted for at least the first half of the fourth century, for which there is actually considerable evidence, then alterations to other key buildings, including the baths and principia, are indicative at least of significant changes of routine. ${ }^{87}$ At the level of an individual site, these variations are small and probably not indicative of the 'breakdown' of coherent military organisation, but taken together with comparable changes across a range of sites, and with the new, rather different fort environments to be found on the Saxon Shore, the broader picture suggests that the common institutional structure of the military in Britain was less influential in practice than it had been previously - and indeed that the workings of local power relationships had been instrumental in creating this situation. ${ }^{88}$ The tensions between tradition and change, conformity and modification, or discipline and discord in practice show that soldiers should not only be seen as successful conquerors, violent oppressors or community-members - though all of these things might have been parts of their experience (and to the extent that these were difficult to reconcile, they become 'discrepant' at the individual level ${ }^{89}$ ). They were also themselves

James 1999, 16-18.

Zienkiewicz 1986a, 37-50.

James 1999, 18-21.

Zienkiewicz 1986b, 17-21.

This is an aspect of élite culture not discussed by Hingley 2005; cf. Mattingly 2011, 220-3, who also emphasises common rather than discrepant experience within the military community.

86 Evans and Metcalf 1992, 57-75.

87 Evans 2010, 166-7

88 cf. Gardner 2007, 217-57; James 1999, 21-3; on the much-discussed issue of later Roman variability in auxiliary barracks, see Hodgson and Bidwell 2004, though cf. Rushworth 2009, 282-316.

89 cf. Krishna 2009, 166-8; Mattingly 2011, 213-16. 


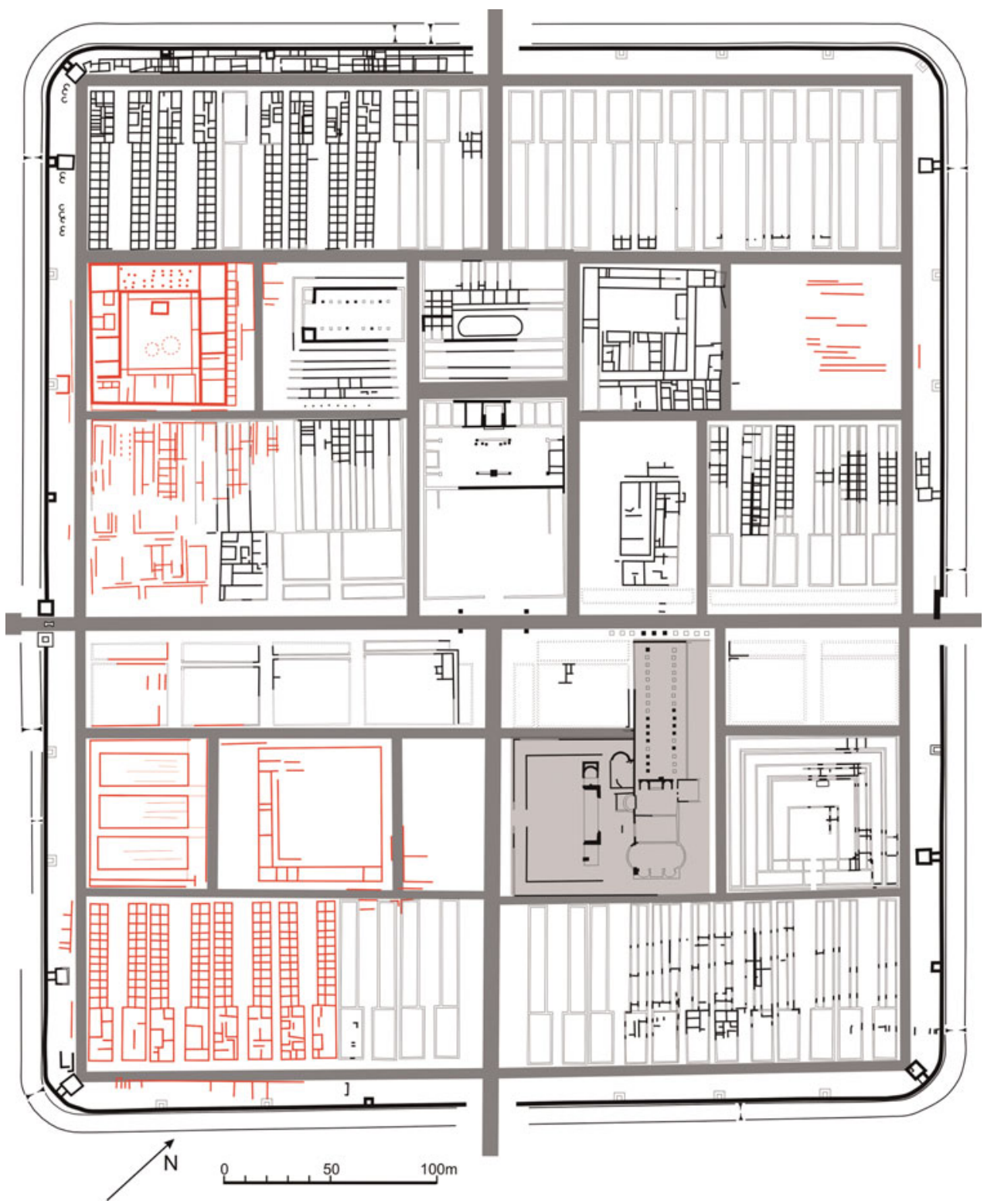

FIG. 1. Plan of Caerleon, with the Fortress Baths highlighted; recent geophysical survey discoveries on the western side of the fortress are outlined in a different shade. (Plan (C) National Museum of Wales, with additions by Tim Young (C) GeoArch)

subaltern — and not just in the original sense of the $\operatorname{word}^{90}$ — and took part in the dynamic process of imperialism as much in how they were made as in what they did. The double-face

90 Krishna 2009, 81; Loomba 2005, 48-9; the meaning of 'subaltern' has shifted from referring to a junior officer to groups of oppressed persons within some postcolonial literature (via the work of Gramsci). Cf. van Driel-Murray 2002, for a study of this process in the auxilia. 
of imperial structures as both the medium for and outcome of the actions of people inhabiting them ${ }^{91}$ is also a key point here, and will be returned to below.

If the analysis of military archaeology in terms of power structures and the intimate relationships between individuals and institutions is already fairly well advanced, and indeed relatively straightforward to pursue given the wealth of evidence available for the comparative analysis of practices and for organisational details, what of other aspects of provincial life? The interpretation of practices apparent in urban and, particularly, rural contexts in terms of power dynamics shaping people as they shaped institutions seems superficially less amenable. ${ }^{92}$ Yet the people of Roman Britain, as of every other province, played their part in creating 'the Roman Empire', and were in turn at least somewhat impacted upon in the process. While the military, at certain times and places, may have formed a significant element of that impact, in most cases we need to examine other kinds of institutional context for people's actions including both other manifestations of state power (provincial or civitas-level bureaucracy), and structures of class, gender, religion and kinship/ethnicity (all of which have relevance to soldiers too, of course). While work on identity and consumption, under the banner of postcolonial and globalisation theories, ${ }^{93}$ has certainly examined the manifestations of these sorts of dimensions of Romano-British life, we need to move beyond the delineation of broad categories and look more carefully at the nature of both subaltern and dominant agencies, and the structural reach of different forms of institution in time and space. The gap between the limits of state involvement in some of these structures, and the more indirect effects of imperialism upon them, also needs to be further defined. ${ }^{94}$ An illustration of the power dynamics of tradition and change in practices in a rural setting can be furnished by a brief examination of some of the recently-published archaeological work in a region not too far from Caerleon, to the east across the Severn Estuary. Comparison of the results from a series of projects in the Cotswolds and Upper Thames Valley provides a useful example of the norms and the variations in a range of practices, and gives some insight into the ways in which institutions overlap in everyday life, with some being more connected to imperial power relationships than others. Increasingly fine detail in the archaeological evidence obtained from different types of rural sites allows us to pursue these theoretical ambitions, and go beyond the existing understanding of social structure in this region as simply being dominated by a 'Roman' urban and/or villa-based élite.

Such an élite was, of course, instrumental in mediating between the civitas-level and provincial administrative institutions and the networks of more regional relationships across the landscape. Yet, even if we accept that their cultural preferences sustained a class-based structure manifest in some sort of 'Roman' identity over a fairly long period, ${ }^{95}$ the ways in which this was created in practice were both variable and dynamic. The institutional norms of élite behaviour were transformative of the people participating in them, but also locally negotiated within existing power structures. Thus at the early villa site at Ditches, for example, built in the later first century A.D. within an Iron Age enclosure (FIG. 2), the strikingly novel building within which the inhabitants dwelled was a manifestation of power over, and probably resources appropriated from, other communities in the surrounding landscape, befitting the new administrative context. Yet in its layout it was an expression as much of links with established sources of novel practices in northern Gaul as with Rome, perhaps themselves mediated by the

cf. Giddens 1984, 25.

However, see Creighton 2006; Revell 2009 on urban settings; Chadwick 2004 on rural.

e.g. Mattingly 2004; Pitts 2008.

Giddens 1985, 56-60 notes the limitations of state power in traditional societies; a postcolonial perspective urges us to look more closely at this issue. Some recent work on consumption is highly relevant here (e.g. Greene 2008; Dietler 2010), but a broader range of practice merits consideration.

95 Hingley 2005, 49-90; Mattingly 2006, 453-71; Millett 1990, 91-101, 117-23, 181-211. 


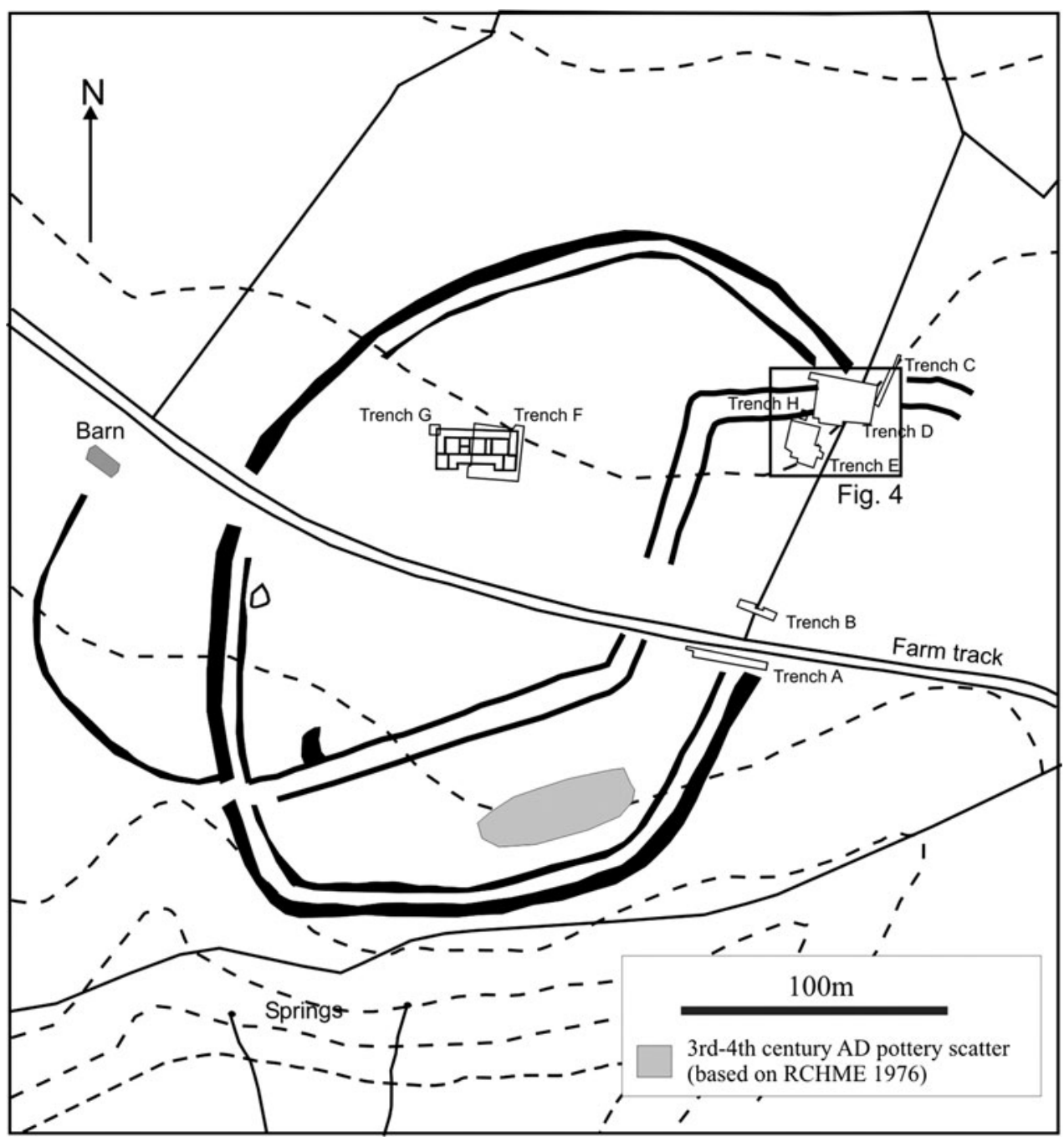

FIG. 2. Plan of the Ditches site, Gloucestershire. (After Trow, James and Moore 2009a, 8)

power structures of the eastern kingdom. ${ }^{96}$ Its physical situation also highlighted stability. Thus existing knowledge of how to create élite status informed a new 'Roman' version of this. Furthermore, the continuity of traditional eating practices ${ }^{97}$ across this transition in architecture and associated routines of dwelling suggests one way in which the impact of being colonised in certain aspects of life was perhaps rebuffed in others. Individuals operating within the élite class structure thus also operated within local traditions of practice, for the benefit of various others (of higher and lower status), and themselves. Multiple sets of institutions were creatively used by these people, but nonetheless perhaps tension - and 'discrepancy' at the individual

96 Trow et al. 2009b.

97 Rielly 2009, 208. 
level — also arose as a result. ${ }^{98}$ The intricate structuring effects of different institutions are further evident at an Upper Thames Valley site of moderately high status, Claydon Pike. This site developed as a nucleated settlement in the early first century A.D., comprising a complex series of enclosures, but was extensively reconfigured in the early second century. At this point, two aisled buildings were constructed, and later in the same century further buildings and a religious precinct were added. In the fourth century, the site was rearranged again, with the building of a stone-founded villa, accompanied by enclosures and a small cemetery. ${ }^{99}$

The transition from the early to the middle Roman period at Claydon Pike is particularly interesting in terms of the ways in which social conventions linked to hierarchy were increasingly realised in practice. Signs of gradually emerging status are discernible in Phase 2 of the site's sequence, encompassing the first century A.D. These are particularly apparent in novel food consumption practices manifest in the pottery assemblage, and the enclosing of the site itself, though the lack of significant change in the small finds assemblage suggests that traditional ways of appearing were still maintained. ${ }^{100}$ The early second century saw significant structural changes, and as the settlement developed over the next two centuries there is much greater evidence for internal differentiation of practices, and of people (FIG. 3). On the basis both of the structural sequence and finds distributions, the excavators have distinguished the higher-status eastern compound containing the two aisled buildings from that to the west (built in the mid-second century). Furthermore, they have identified a prominent boundary flanking an open area between the two zones. While such evidence, along with increasing indications of personal differentiation from the small finds, is strongly suggestive of social boundaries between status groups - perhaps owners and workers - evidence of possibly more communal (or at least conspicuous) feasting comes from some of the assemblages of pottery and animal bone. ${ }^{101}$ The actions of people living on the site during the second and third centuries were thus materially constrained by institutionalised status distinctions. Power differentials between individuals were continually created by the architecture of the site, yet because such differentiation is always potentially open to challenge (subject to the 'dialectic of control' as much as the lives of soldiers discussed above), continued legitimisation of the norms of day-to-day life was required, a purpose which feasting activity probably served. The economy of the site (apparently geared towards hay-making on a significant scale, perhaps for the urban market), ${ }^{102}$ which provided the resources for this particular local institutional negotiation, also connected the site into further power networks elsewhere in the region, particularly those centred upon Cirencester.

Both sites discussed so far can thus be placed into a broader context to begin sketching out the institutional landscape which characterised the Cotswolds and the Upper Thames Valley. While there was generally continuity in the settlement pattern across the period of Roman conquest, and evidence of pre-Roman centres of power at different scales continuing to be important, ${ }^{103}$ the sites discussed above show that these might take different forms and have rather different histories. A fairly flexible set of political institutions thus structured this region at least until the early second century. From this period, greater involvement in novel civic and economic structures at Cirencester doubtless had something to do with changes observable at sites like Claydon Pike, but as élite identity was also embedded in local institutions of kinship and status, the expression of this was still quite variable. Indeed, the patchwork of colonial

101 Smith 2007c.

102 Smith 2007c, 165

103 Smith 2007d, 381. 


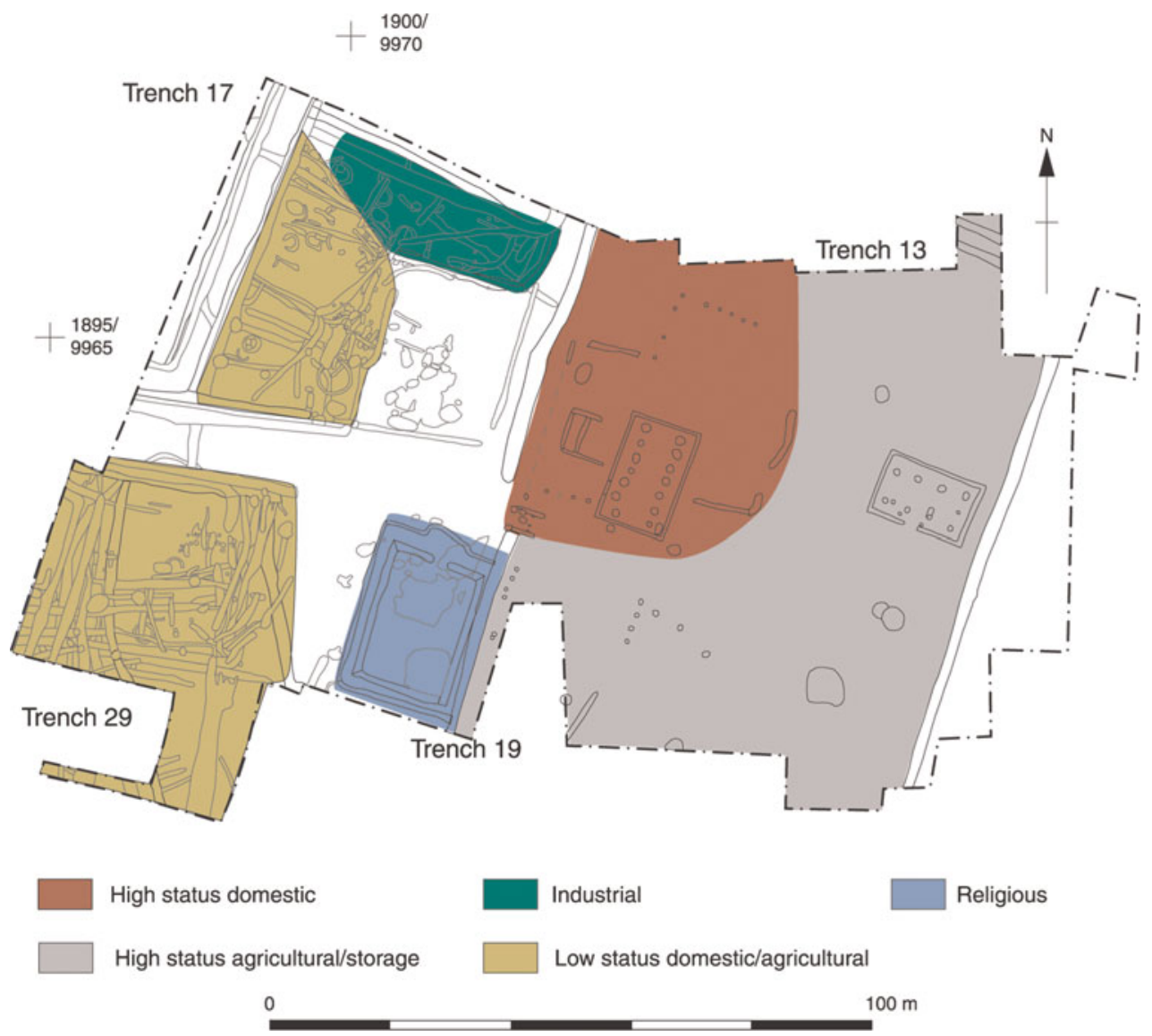

FIG. 3. Plan of Phase 3 at Claydon Pike, Upper Thames Valley, with major functional/activity areas shaded. (After Miles et al. 2007, 162; (C) Oxford Archaeology)

experiences just within this region has only recently begun to emerge from the archaeology. ${ }^{104}$ Even on sites with fewer indications of status, the role of various kinds of institution, both traditional and novel, can still be discerned. A site like Cotswold Community, closer to Cirencester than Claydon Pike and with some signs of economic relationships to the town, shared in the early second-century transformation common to much of the area. At this time, the structures of empire apparently bore down quite directly on the inhabitants of this site. More subtly, the gradual encroachment of new technologies of eating, appearance and exchange, although occurring to a less marked degree than at sites like Claydon Pike, also had a transformative effect on interpersonal interactions and on the tempo of change in material life. Whether or not these alterations to everyday routines were viewed positively, other activities were deliberately mobilised to express continuity of place, through, for example, placing burials near Bronze Age and Early Iron Age features in the immediately surrounding landscape. ${ }^{105}$

104 Smith 2007d, 385-6.

105 Smith and Powell 2010; Gardner 2012a contains a more detailed analysis of changing practices at Cotswold Community; cf. also Chadwick 2004. 
Thus, the maintenance of something of a balance of power between imperial, regional and local institutions was negotiated by individuals even on a relatively low status site, as comparison of different spheres of practice reveals. Understanding such processes more fully, and across wider areas, is perhaps the key priority in the archaeology of rural settlement, and will reveal much about the nature of Roman imperialism in Britain. ${ }^{106}$

Although limitations of space prohibit further exemplification of the approach advocated here, an attempt has been made to give an outline of how it brings the role of power in the process of imperialism to the foreground by focusing not just on practice as such, but on the way individuals and diverse structures interacted through that medium. In doing this, the notion of 'institutional archaeology' builds upon a good deal of work already at least partially explored in the context of Roman archaeology. Indeed, Eleanor Scott laid very clear emphasis on the interaction of agency and structure at the outset of the articulation of a theoretical Roman archaeology. ${ }^{107}$ In the preceding sections, it has been argued that crucial aspects of this interaction in the Roman world have become somewhat neglected in the last two decades or so, though they are certainly not incompatible with other theoretical developments, particularly the questions posed by postcolonial theory. ${ }^{108}$ Indeed, part of the reason for arguing for a renewed commitment to these conceptual tools is that in the wider field of archaeology, too, the potential of an archaeology of agency, structure and practice has been fleetingly developed, then hastily cast aside as intellectual fashions changed, but is now lamented. ${ }^{109}$ Roman archaeology can both draw upon and contribute to this ongoing debate, and in doing so move forward with the analysis - and not just the re-description - of Roman imperialism, in a fashion which does not seek a replacement for 'Romanisation'. This will not be found, because no such one-dimensional concept can capture both the way in which empire transformed people and the way in which people transformed - indeed, created - empire. It was in the creation of an empire and the interaction between diverse groups of people that much of what defines the Roman Empire as 'Roman' came into being. ${ }^{110}$ Imperialism does thus need to be seen as a process unfolding in time, but one in which the empire is both the medium for and outcome of a great range of social, political, economic and cultural interactions. ${ }^{111}$ Keeping traditions and innovations in practice, the formation of communities of practice and institutions, and the nesting of identities and power-flows at the heart of our thinking about Roman imperialism will help us to capture both what is particular about it, and thus how we might profitably compare it with other societies.

\section{CONCLUSION: THE WEB OF PAST AND PRESENT}

This paper has sought to evaluate two of the major strands of 'theoretical Roman archaeology' that have emerged over the last twenty years. Certainly there are other themes which have gradually become integrated into the mainstream of Roman archaeology, such as social memory or

106 cf. Taylor 2007, 118; Wiggins forthcoming.

107 Scott 1993b, 13-15; cf. and contra Mattingly 2011, 216 on terminology. Creighton 2006 and Revell 2009 both make subtle use of this kind of approach.

108 Krishna 2009, 155-72; cf. González-Ruibal 2010, 45.

109 e.g. Harding 2008, 161; Hegmon, 2003, 219-22; Johnson 2010, 224-6; Joyce and Lopiparo 2005. The failure to move beyond the recovery of agency to a fuller analysis of structuration is perhaps attributable to the perception that structure was already all-too well understood. The same is perhaps the case even in sociology; cf. López and Scott 2000, $1-2$.

110 Gosden 2004, 24, 33-40, 104-13, 116; Mattingly 2011, 25-6; Woolf 1995; cf. Krishna 2009, 69, 163-8; Loomba 2005, 20-2; Said 1993, 40-5; Young 2001, 68.

111 cf. Mattingly 2011, 270-2; contra Rosenberg 2000, 3. 
landscape perception, but these two perhaps most encapsulate shifting ideas about the nature of Roman imperialism for the post-'Romanisation' generation. All theories have strengths and weaknesses, and the wider literature on both postcolonialism and globalisation is itself replete with divergent views, critiques and counter-arguments. Thus, it should be no surprise that certain problems of coherence, particularly to do with reconciling description, analysis and judgement, and the handling of multiple scales of phenomena, become manifest not so much in the work of individuals, but in the big picture of where Roman archaeology is heading. Fragmentation of narratives about the Roman world is in some sense desirable, and indeed inevitable, as we increasingly unpick the great complexity of that world. This fragmentation certainly fits with the times, in the sense that just as every age creates its own Roman Empire, at this point there is a multiplicity of competing popular understandings of Rome. ${ }^{12}$ However, just as in the archaeology of other times and places, there is a danger that fragmentation breeds disengagement between different perspectives, and that core problems slip between the cracks. ${ }^{113}$ For all of the useful ideas that readings of postcolonial theory and globalisation studies have brought into Roman archaeology, the situation outlined above is one in which core issues of power and scale in the institutional articulation of empire have started to take a back seat. This is important not just because of the role that continued attention to these issues ought to take in enhancing our understanding of the Roman world, but also in relation to the purpose of theorising Roman archaeology. Critics of theoretical archaeology sometimes point to the perception that new ideas or terminologies rarely seem to make much difference to the bread-and-butter descriptive categories of empirical data, ${ }^{114}$ but this is really only a symptom of the level of inertia that has accumulated in all areas of archaeology over the last century or more. Really significant change in the practice and theory of archaeology takes patience and demands that sub-disciplines with a broad range of evidential resources play their part in theory-building at every level, from site formation studies to analyses of major phenomena like imperialism. ${ }^{15}$ Such change is needed because - as the debate over 'Romanisation' shows the old categories are not fit for purpose, but we are still working out what the new ones should be. In this paper it is argued that reconnecting some of the insights from postcolonial and globalisation theories with the ongoing debate over structure, agency and practice would be a step in the right direction. Far from having had their day, such conceptual tools have barely begun to be adequately worked through, and they offer something too to understanding the place of Roman archaeology in the present.

This remains the underlying question: what is Roman archaeology for? ${ }^{116}$ There are probably several answers to this question, depending upon how we define 'Roman archaeology'. Certainly popular interest in accessible windows into the Roman world seems buoyant — to judge not only from television and film, but also from visitors to ongoing excavations. ${ }^{117}$ There is something of a disconnect between this interest and some of the activities of Roman scholars, whether empirically or theoretically-minded. This is not entirely to be decried, since some specialist work is necessary to build a bigger picture in the long-run, as argued here; ultimately though there must be broader dialogue about that big picture. There is a disconnect, too, between Roman archaeology and other areas of interdisciplinary interest that span archaeology, other classical disciplines, and

112 cf. Hingley forthcoming; Mattingly 2011, 3-5; Rothe 2006; Witcher forthcoming; Woolf 2004.

113 cf. Gardner and Cochrane 2011, 11-13.

114 e.g. de la Bédoyère 2007; cf. Johnson 2010, 224

115 cf. Scott 1993b, 14-21; the lack of detailed studies of site/assemblage formation issues in Roman archaeology is a notable gap (one example is Peña 2007), and there is also room to build on the now quite common publication of small finds according to functional categories, by treating all finds in site reports in terms of practices (as in Barrett et al. 2000).

116 Hingley 2003, 119.

117 Mattingly 2011, 3-5; Gardner and Guest 2010, 50. 
other social sciences, as discussed above. Triangulating between these different domains more effectively seems essential and must come through continual modification of our practice. The Roman Empire is of interest both to other scholars and to a wide range of other audiences because it is both comparable to the present in various ways - whether in terms of empire and resistance to it, or other aspects such as technological change - and yet also distinctive. But it is also significant because it is causally connected to many structural features of the contemporary world, at least in terms of symbolic resources, and albeit through the varied permutations of reinvention that have occurred from the Roman period itself onwards. Looking ahead, the practice of Roman archaeology needs to seek greater engagement with both other archaeologists and the public, with the aim of nourishing not a particular vision of Rome as benevolent/evil empire, pre-modern global system, or whatever, but rather a critical understanding of how culture and colonialism have intertwined in shaping the world we live in. As new discoveries continue to remind us of how little we know about even well-explored sites, ${ }^{118}$ we should also be mindful of how inadequate our theories about the Roman world have been. Efforts in both kinds of practice need to come together to refresh Roman archaeology for the twenty-first century.

\section{ACKNOWLEDGEMENTS}

This paper is the result of a long process of thinking about Roman imperialism, and a number of conference papers over the last two or three years have been important steps along the way; thanks are therefore owed to John Robb and Charles Cobb, Pete Wilson, and Bruce Hitchner and David Mattingly for invitations to contribute to sessions at SAA 2009, RAC 2009, and RAC 2010. I am also grateful to a number of other colleagues, including many fellow TRAC-travellers, for discussions about several of the themes considered here over recent years. The paper has been much improved by helpful comments from the referees, and I would also like to thank Richard Hingley and Rob Witcher for advance copies of forthcoming papers. Finally, I am indebted to Richard Brewer, Tim Young, Magdalena Wachnik, Simon James, Stephen Trow and Tom Moore for assistance with, and permission to use, illustrations.

Institute of Archaeology, UCL

andrew.gardner@ucl.ac.uk

\section{BIBLIOGRAPHY}

Adam, B. 1994: 'Perceptions of time', in T. Ingold (ed.), Companion Encyclopedia of Anthropology: Humanity, Culture and Social Life, London, 503-26

Allison, P.M. 2009: 'Understanding Pompeiian household practices through their material culture', Facta 3, $11-32$

Andrén, A. 1998: Between Artifacts and Texts: Historical Archaeology in Global Perspective (trans. A. Crozier), New York

Baker, P. 2003: 'A brief comment on the TRAC session dedicated to interdisciplinary approaches to the study of Roman women', in Carr et al. 2003, 140-6

Barrett, J.C. 1997: 'Romanization: a critical comment', in Mattingly 1997, 51-64

Barrett, J.C., Freeman, P.W.M., and Woodward, A. 2000: Cadbury Castle, Somerset: The Later Prehistoric and Early Historical Archaeology, London

Bédoyère, G. de la 2007: 'Romanization', British Archaeology 92 (Jan/Feb), 22

Biddulph, E. 2012: 'On cultural selection: examining the process of cultural evolution through funerary evidence', in M. Duggan, F. McIntosh and D. Rohl (eds), TRAC 2011: Proceedings of the 21st Annual Theoretical Roman Archaeology Conference, Newcastle 2011, Oxford, 76-90

118 Guest 2010. 
Bradley, M. (ed.) 2010: Classics and Imperialism in the British Empire, Oxford

Carr, G., Swift, E., and Weekes, J. (eds) 2003: TRAC 2002: Proceedings of the Twelfth Annual Theoretical Roman Archaeology Conference, Canterbury 2002, Oxford

Casella, E.C., and Fowler, C. (eds) 2005: The Archaeology of Plural and Changing Identities: Beyond Identification, New York

Chadwick, A.M. 2004: "'Heavier burdens for willing shoulders?" Writing different histories, humanities and social practices for the Romano-British countryside', in Croxford et al. 2004, 90-110

Cioffi-Revilla, C. 2000: 'War and warfare: scales of conflict in long-range analysis', in Denemark et al. 2000a, 253-72

Cochrane, E.E., and Gardner, A. (eds) 2011: Evolutionary and Interpretive Archaeologies: A Dialogue, Walnut Creek, CA

Collins, R. 2008: 'Identity in the frontier: theory and multiple community interfacing', in Fenwick et al. 2008, 45-52

Creighton, J. 2006: Britannia: The Creation of a Roman Province, London

Croxford, B., Eckardt, H., Meade, J., and Weekes, J. (eds) 2004: TRAC 2003: Proceedings of the Thirteenth Annual Theoretical Roman Archaeology Conference, Leicester 2003, Oxford

Croxford, B., Goodchild, H., Lucas, J., and Ray, N. (eds) 2006: TRAC 2005: Proceedings of the Fifteenth Annual Theoretical Roman Archaeology Conference, Birmingham 2005, Oxford

Cunliffe, B. 1988: Greeks, Romans and Barbarians: Spheres of Interaction, London

Dench, E. 2003: Review of S. Keay and N. Terrenato (eds), Italy and the West: Comparative Issues in Romanization, Journal of Roman Studies 93, 327-9

Dench, E. 2005: Romulus' Asylum: Roman Identities from the Age of Alexander to the Age of Hadrian, Oxford

Denemark, R.A., Friedman, J., Gills, B.K., and Modelski, G. (eds) 2000a: World System History: The Social Science of Long-term Change, London

Denemark, R.A., Friedman, J., Gills, B.K., and Modelski, G. (eds) 2000b: 'An introduction to world system history: toward a social science of long-term change', in Denemark et al. 2000a, $\mathrm{xv}-\mathrm{xxii}$

Díaz-Andreu, M. 2007: A World History of Nineteenth Century Archaeology: Nationalism, Colonialism, and the Past, Oxford

Díaz-Andreu, M., Lucy, S., Babić, S., and Edwards, D.N. 2005: The Archaeology of Identity: Approaches to Gender, Age, Status, Ethnicity and Religion, London

Dietler, M. 2010: Archaeologies of Colonialism: Consumption, Entanglement, and Violence in Ancient Mediterranean France, Berkeley, CA

Dommelen, P. van, and Terrenato, N. (eds) 2007: Articulating Local Cultures: Power and Identity under the Expanding Roman Republic, Portsmouth, RI

Doyle, M.W. 1986: Empires, Ithaca, NY

Driel-Murray, C. van 1995: 'Gender in question', in P. Rush (ed.), Theoretical Roman Archaeology: Second Conference Proceedings, Aldershot, 3-21

Driel-Murray, C. van 2002: 'Ethnic soldiers: the experience of the lower Rhine tribes', in T. Grünewald and G. Seibel (eds), Kontinuität und Diskontinuität: Germania Inferior am Beginn und am Ende der römischen Herrschaft, Berlin, 200-17

Driessen, M. 2005: 'Unifying aspects of Roman forts', in J. Bruhn, B. Croxford and D. Grigoropoulos (eds), TRAC 2004: Proceedings of the Fourteenth Annual Theoretical Roman Archaeology Conference, Durham 2004, Oxford, 157-62

Evans, D.R., and Metcalf, V.M. 1992: Roman Gates Caerleon, Oxford

Evans, E.M. 2010: 'Caerleon', in B.C. Burnham and J.L. Davies (eds), Roman Frontiers in Wales and the Marches, Aberystwyth, 161-72

Faulkner, N. 2008: 'Roman archaeology in an epoch of neoliberalism and imperialist war', in Fenwick et al. 2008, 63-73

Fenwick, C., Wiggins, M., and Wythe, D. (eds) 2008: TRAC 2007: Proceedings of the Seventeenth Annual Theoretical Roman Archaeology Conference, London 2007, Oxford

Fewster, K. forthcoming: 'On practice', in A. Gardner, M. Lake and U. Sommer (eds), The Oxford Handbook of Archaeological Theory, Oxford 
Forcey, C. 1997: 'Beyond "Romanization": technologies of power in Roman Britain', in K. Meadows, C. Lemke and J. Heron (eds), TRAC 96: Proceedings of the Sixth Annual Theoretical Roman Archaeology Conference, Sheffield 1996, Oxford, 15-21

Frank, A.G., and Gills, B.K. 2000: 'The five thousand year world system in theory and praxis', in Denemark et al. 2000a, 3-23

Freeman, P.W.M. 1993: “Romanisation” and Roman material culture', Journal of Roman Archaeology 6, $438-45$

Frere, S.S. 1988: 'Roman Britain since Haverfield and Richmond', History and Archaeology Review 3, 31-6 Frere, S.S. 1999: Britannia: A History of Roman Britain (Folio edn), London

Fulford, M. 2007: 'An insular obsession', Britannia 38, 367-9

Gardner, A. 2003: 'Debating the health of Roman archaeology', Journal of Roman Archaeology 16, 435-41

Gardner, A. 2006: 'The future of TRAC', in Croxford et al. 2006, 128-37

Gardner, A. 2007: An Archaeology of Identity: Soldiers and Society in Late Roman Britain, Walnut Creek, CA

Gardner, A. 2011: 'Action and structure in interpretive archaeologies', in Cochrane and Gardner 2011, 63-82

Gardner, A. 2012a: 'Time and empire in the Roman world', Journal of Social Archaeology 12.2, 145-66

Gardner, A. 2012b: Review of A. Moore et al. (eds), TRAC 2009, Britannia 43, 451-2

Gardner, A., and Cochrane, E.E. 2011: 'Evolutionary and interpretive archaeologies: a dialogue', in Cochrane and Gardner 2011, 11-29

Gardner, A., and Guest, P. 2010: 'Exploring Roman Caerleon: new excavations at the legionary fortress of Isca', Archaeology International 12, 47-51

Giddens, A. 1984: The Constitution of Society: Outline of the Theory of Structuration, Cambridge

Giddens, A. 1985: The Nation-state and Violence (Volume Two of A Contemporary Critique of Historical Materialism), Cambridge

Giddens, A. 1990: The Consequences of Modernity, Cambridge

Giddens, A. 1991: Modernity and Self-Identity: Self and Society in the Late Modern Age, Cambridge

Given, M. 2004: The Archaeology of the Colonized, London

Goff, B. (ed.) 2005: Classics and Colonialism, London

González-Ruibal, A. 2010: 'Colonialism and European archaeology', in Lydon and Rizvi 2010a, 39-50

Gosden, C. 1999: Anthropology and Archaeology: A Changing Relationship, London

Gosden, C. 2004: Archaeology and Colonialism: Cultural Contact from 5000BC to the Present, Cambridge

Gosden, C. 2005: 'What do objects want?', Journal of Archaeological Method and Theory 12.3, 193-211

Greene, K. 2006: 'Evolutionary metaphors and the Roman economy', in E. Lo Cascio (ed.), Innovazione tecnica e progresso economico nel mondo romano, Bari, 271-302

Greene, K. 2008: 'Learning to consume: consumption and consumerism in the Roman Empire', Journal of Roman Archaeology 21.1, 64-82

Guest, P. 2010: 'Monumental discovery', http://www.cardiff.ac.uk/news/articles/monumental-discovery4436.html

Hales, S., and Hodos, T. (eds) 2010: Material Culture and Social Identities in the Ancient World, Cambridge Hanson, W.S. 1997: 'Forces of change and methods of control', in Mattingly 1997, 67-80

Harding, A. 2008: 'A conversation with Colin Renfrew (Professor Lord Renfrew of Kaimsthorn)', European Journal of Archaeology 11.2-3, 143-70

Hardt, M., and Negri, A. 2000: Empire, Cambridge, MA

Hardwick, L., and Gillespie, C. (eds) 2007: Classics in Postcolonial Worlds, Oxford

Haynes, I. 1999: 'Military service and cultural identity in the auxilia', in I. Haynes and A. Goldsworthy (eds), The Roman Army as a Community, Portsmouth, RI, 165-74

Hegmon, M. 2003: 'Setting theoretical egos aside: issues and theory in North American archaeology', American Antiquity 68.2, 213-43

Hingley, R. 1996: 'The "legacy" of Rome: the rise, decline, and fall of the theory of Romanization', in Webster and Cooper 1996, 35-48

Hingley, R. 2000: Roman Officers and English Gentlemen: The Imperial Origins of Roman Archaeology, London

Hingley, R. 2001: 'A comment on Ray Laurence's Roman narratives: the writing of archaeological discourses - a view from Britain?', Archaeological Dialogues 8.2, 111-14 
Hingley, R. 2003: 'Recreating coherence without reinventing Romanization', Digressus, Supplement 1, 11119 (http://www.digressus.org)

Hingley, R. 2005: Globalizing Roman Culture: Unity, Diversity and Empire, London

Hingley, R. 2007: 'Situating a post-colonial Roman Britain', Journal of Roman Archaeology 20.2, 535-40

Hingley, R. 2008: The Recovery of Roman Britain, 1586-1906: A Colony so Fertile, Oxford

Hingley, R. 2010: 'Cultural diversity and unity: empire and Rome', in Hales and Hodos 2010, 54-75

Hingley, R. forthcoming: 'Post-colonial and global Rome: the genealogy of Empire', in Pitts and Versluys forthcoming

Hitchner, R.B. 2008: 'Globalization avant la lettre: globalization and the history of the Roman Empire', New Global Studies, 2.2, 1-12

Hodder, I. 1993: 'Bridging the divide: a commentary on theoretical Roman archaeology', in Scott 1993a, xiii-xix

Hodgson, N., and Bidwell, P.T. 2004: 'Auxiliary barracks in a new light: recent discoveries on Hadrian's Wall', Britannia 35, 121-57

Hodos, T. 2010: 'Local and global perspectives in the study of social and cultural identities', in Hales and Hodos 2010, 3-31

Hopkins, A.G. 2002: 'Introduction: globalization - an agenda for historians', in A.G. Hopkins (ed.), Globalization in World History, London, 1-10

James, S. 1999: 'The community of the soldiers: a major identity and centre of power in the Roman Empire', in P. Baker, C. Forcey, S. Jundi and R. Witcher (eds), TRAC 98: Proceedings of the Eighth Annual Theoretical Roman Archaeology Conference, Leicester 1998, Oxford, 14-25

James, S. 2001a: "'Romanization" and the peoples of Britain', in S. Keay and N. Terrenato (eds), Italy and the West: Comparative Issues in Romanization, Oxford, 187-209

James, S. 2001b: 'Soldiers and civilians: identity and interaction in Roman Britain', in S. James and M. Millett (eds), Britons and Romans: Advancing an Archaeological Agenda, York, 77-89

James, S. 2003: 'Roman Archaeology: crisis and revolution', Antiquity 77 (295), 178-84

James, S. 2011: 'Interpretive approaches, violence and evolutionary approaches', in Cochrane and Gardner 2011, 127-49

Jenkins, R. 2004: Social Identity (2nd edn), London

Jennings, J. 2011: Globalizations and the Ancient World, Cambridge

Johnson, M.H. 1999: 'Rethinking historical archaeology', in P.P.A. Funari, M. Hall and S. Jones (eds), Historical Archaeology: Back from the Edge, London, 23-36

Johnson, M. 2010: Archaeological Theory: An Introduction (2nd edn), Chichester

Joyce, R.A., and Lopiparo, J. 2005: 'Postscript: doing agency in archaeology', Journal of Archaeological Method and Theory 12.4, 365-74

Kohl, P.L., and Fawcett, C. 1995: 'Archaeology in the service of the state: theoretical considerations', in P.L. Kohl and C. Fawcett (eds), Nationalism, Politics and the Practice of Archaeology, Cambridge, 3-18

Krishna, S. 2009: Globalization and Postcolonialism: Hegemony and Resistance in the Twenty-First Century, Lanham, MD

Laurence, R. 1999a: 'Theoretical Roman Archaeology', Britannia 30, 387-90

Laurence, R. 1999b: The Roads of Roman Italy: Mobility and Cultural Change, London

Laurence, R. 2001: 'Roman narratives: the writing of archaeological discourse - a view from Britain? (with comments and reply)', Archaeological Dialogues 8.2, 90-122

Laurence, R. 2006: '21st century TRAC: is the Roman battery flat?', in Croxford et al. 2006, 116-27

Leone, M.P. 2005: The Archaeology of Liberty in an American Capital: Excavations in Annapolis, Berkeley

Lightfoot, K.G., Martinez, A., and Schiff, A.M. 1998: 'Daily practice and material culture in pluralistic social settings: an archaeological study of culture change and persistence from Fort Ross, California', American Antiquity 63.2, 199-22

Loomba, A. 2005: Colonialism/Postcolonialism (2nd edn), London

López, J., and Scott, J. 2000: Social Structure, Buckingham

Lydon, J., and Rizvi, U.Z. (eds) 2010a: Handbook of Postcolonial Archaeology, Walnut Creek, CA

Lydon, J., and Rizvi, U.Z. 2010b: 'Introduction: postcolonialism and archaeology', in Lydon and Rizvi 2010a, 17-33

Malešević, S. 2010: The Sociology of War and Violence, Cambridge 
Martins, C. 2003: 'Becoming consumers: looking beyond wealth as an explanation for villa variability', in Carr et al. 2003, 84-100

Mattingly, D.J. 1996: 'From one colonialism to another: imperialism and the Maghreb', in Webster and Cooper 1996, 49-69

Mattingly, D.J. (ed.) 1997: Dialogues in Roman Imperialism, Portsmouth, RI

Mattingly, D.J. 2004: 'Being Roman: expressing identity in a provincial setting', Journal of Roman Archaeology 17, 5-25

Mattingly, D.J. 2006: An Imperial Possession: Britain in the Roman Empire, 54BC-AD409, London

Mattingly, D.J. 2010: 'Cultural crossovers: global and local identities in the Classical world', in Hales and Hodos 2010, 283-95

Mattingly, D.J. 2011: Imperialism, Power and Identity: Experiencing the Roman Empire, Princeton, NJ

Meskell, L. 2002: 'The intersections of identity and politics in archaeology', Annual Review of Anthropology 31, 279-301

Miles, D., Palmer, S., Smith, A., and Perpetua Jones, G. 2007: Iron Age and Roman Settlement in the Upper Thames Valley: Excavations at Claydon Pike and Other Sites within the Cotswold Water Park, Oxford

Miller, D. (ed.) 1995: Worlds Apart: Modernity through the Prism of the Local, London

Millett, M. 1990: The Romanization of Britain: An Essay in Archaeological Interpretation, Cambridge

Moreland, J. 2001: Archaeology and Text, London

Morley, N. 2010: The Roman Empire: Roots of Imperialism, London

Morrison, K.D. 2001: 'Sources, approaches, definitions', in S.E. Alcock, T.N. D'Altroy, K.D. Morrison and C.M. Sinopoli (eds), Empires: Perspectives from Archaeology and History, Cambridge, 1-9

Münkler, H. 2007 [2005]: Empires: The Logic of World Domination from Ancient Rome to the United States (trans. P. Camiller), Cambridge

Naerebout, F.G. 2007: 'Global Romans? Is globalisation a concept that is going to help us understand the Roman Empire?', Talanta 38/39, 149-70

Nederveen Pieterse, J. 2009: Globalization and Culture: Global Mélange (2nd edn), Lanham, MD

O'Hanlon, R., and Washbrook, D. 1992: 'After Orientalism: culture, criticism, and politics in the Third World', Comparative Studies in Society and History 34.1, 141-67

Otto, T., Thrane, H., and Vandkilde, H. (eds) 2006: Warfare and Society: Archaeological and Social Anthropological Perspectives, Aarhus

Peddie, J. 1994: The Roman War Machine, Stroud

Peña, J.T. 2007: Roman Pottery in the Archaeological Record, Cambridge

Pitts, M. 2004: “'I drink, therefore I am?” Pottery consumption and identity at Elms Farm, Heybridge, Essex', in Croxford et al. 2004, 16-27

Pitts, M. 2007: 'The emperor's new clothes? The utility of identity in Roman archaeology', American Journal of Archaeology 111, 693-713

Pitts, M. 2008: 'Globalizing the local in Roman Britain: an anthropological approach to social change', Journal of Anthropological Archaeology 27, 493-506

Pitts, M. 2010: 'Artefact suites and social practice: an integrated approach to Roman provincial finds assemblages', Facta 4, 125-52

Pitts, M., and Versluys, M.J. (eds) forthcoming: Globalisation and the Roman World: Perspectives and Opportunities, Cambridge

Poitevin, G. 2002: The Voice and the Will. Subaltern Agency: Forms and Motives, New Delhi

Pollard, N. 1996: 'The Roman army as a "total institution" in the Near East? Dura-Europos as a case study', in D.L. Kennedy (ed.), The Roman Army in the East, Ann Arbor, MI, 211-27

Porter, A. 2010: "Akkad and agency, archaeology and annals: considering power and intent in third millennium BCE Mesopotamia', in S.R. Steadman and J.C. Ross (eds), Agency and Identity in the Ancient Near East: New Paths Forward, London, 166-80

Ratliff, M.L. 2011: 'Globalisation, consumerism and the ancient Roman economy: a preliminary look at bronze and iron production and consumption', in D. Mladenović and B. Russell (eds), TRAC 2010: Proceedings of the Twentieth Annual Theoretical Roman Archaeology Conference, Oxford 2010, Oxford, 32-46

Reece, R. 1997: 'Writing Roman Britain: past indicative, future perfect?', Britannia 28, 473-8

Revell, L. 2009: Roman Imperialism and Local Identities, Cambridge 
Revell, L. 2010: 'Romanization: a feminist critique', in A. Moore, G. Taylor, E. Harris, P. Girdwood and L. Shipley (eds), TRAC 2009: Proceedings of the 19th Annual Theoretical Roman Archaeology Conference, Michigan and Southampton 2009, Oxford, 1-10

Rielly, K. 2009: 'Animal bone', in Trow et al. 2009a, 187-209

Rogers, A., and Hingley, R. 2010: 'Edward Gibbon and Francis Haverfield: the traditions of imperial decline', in M. Bradley (ed.), Classics and Imperialism in the British Empire, Oxford, 189-209

Rosenberg, J. 2000: The Follies of Globalisation Theory: Polemical Essays, London

Roth, R.E. 2007: Styling Romanisation: Pottery and Society in Central Italy, Cambridge

Roth, R., and Keller, J. (eds) 2007: Roman by Integration: Dimensions of Group Identity in Material Culture and Text, Portsmouth, RI

Rothe, U. 2006: 'Roman globalisation', The Classical Review 56.2, 441-4

Roymans, N. 2004: Ethnic Identity and Imperial Power: The Batavians in the Early Roman Empire, Amsterdam Rushworth, A. 2009: Housesteads Roman Fort - The Grandest Station, Volume 1: Structural Report and Discussion, Swindon

Said, E.W. 1993: Culture and Imperialism, London

Scholte, J.A. 2005: Globalization: A Critical Introduction (2nd edn), Houndmills

Scott, E. (ed.) 1993a: Theoretical Roman Archaeology: First Conference Proceedings, Aldershot

Scott, E. 1993b: 'Writing the Roman Empire', in Scott 1993a, 5-22

Selkirk, A. 2006: Review of D. Mattingly, An Imperial Possession: Britain in the Roman Empire, Current Archaeology 205 (18.1), 30

Smith, A. 2007a: 'The Cotswold Water Park Project', in Miles et al. 2007, 1-10

Smith, A. 2007b: 'Discussion [Chapter 4]', in Miles et al. 2007, 87-92

Smith, A. 2007c: 'Discussion [Chapter 5]', in Miles et al. 2007, 159-67

Smith, A. 2007d: 'The Late Iron Age and Roman landscape', in Miles et al. 2007, 391-403

Smith, A., and Powell, K. 2010: 'In the shadow of Corinium: the later Iron Age to late Roman period', in K. Powell, A. Smith and G. Laws, Evolution of a Farming Community in the Upper Thames Valley: Excavation of a Prehistoric, Roman and post-Roman Landscape at Cotswold Community, Gloucestershire and Wiltshire, Oxford, 99-187

Stein, G.J. (ed.) 2005: The Archaeology of Colonial Encounters: Comparative Perspectives, Santa Fe

Taylor, J. 2007: An Atlas of Roman Rural Settlement in England, York

Thomas, J. 2004: Archaeology and Modernity, London

Trigger, B.G. 2006: A History of Archaeological Thought (2nd edn), Cambridge

Trow, S., James, S., and Moore, T. 2009a: Becoming Roman, Being Gallic, Staying British: Research and Excavations at Ditches 'Hillfort' and Villa 1984-2006, Oxford

Trow, S., James, S., and Moore, T. 2009b: 'Discussion of the Iron Age and Roman remains', in Trow et al. 2009a, 45-75

Urry, J. 2000: Sociology Beyond Societies: Mobilities for the 21st Century, London

Webster, J. 1996a: 'Roman imperialism and the "post-imperial age"', in Webster and Cooper 1996, 1-17

Webster, J. 1996b: 'Ethnographic barbarity: colonial discourse and "Celtic warrior societies"', in Webster and Cooper 1996, 111-23

Webster, J. 2001: 'Creolizing the Roman provinces', American Journal of Archaeology 105, 209-25

Webster, J., and Cooper, N. (eds) 1996: Roman Imperialism: Post-colonial Perspectives, Leicester

Wiggins, M. forthcoming: Roman Households: Space, Status and Identity, $\mathrm{PhD}$ thesis, University of London

Winkler, M.M. (ed.) 2004: Gladiator: Film and History, Oxford

Witcher, R. 2000: 'Globalisation and Roman imperialism: perspectives on identities in Roman Italy', in E. Herring and K. Lomas (eds), The Emergence of State Identities in Italy in the 1st Millennium BC, London, 213-25

Witcher, R. forthcoming: 'Globalisation and Roman cultural heritage', in Pitts and Versluys forthcoming

Woolf, G. 1995: 'The formation of Roman provincial cultures', in J. Metzler, M. Millett, N. Roymans and J. Slofstra (eds), Integration in the Early Roman West: The Role of Culture and Ideology, Luxembourg, 9-18

Woolf, G. 2004: 'The present state and future scope of Roman archaeology: a comment', American Journal of Archaeology 108, 417-28

Young, R.J.C. 2001: Postcolonialism: an Historical Introduction, Oxford

Zienkiewicz, J.D. 1986a: The Legionary Fortress Baths at Caerleon, I: The Buildings, Cardiff

Zienkiewicz, J.D. 1986b: The Legionary Fortress Baths at Caerleon, II: The Finds, Cardiff 